\title{
Effect of Composted Rock Phosphate with Organic Materials on Yield and Phosphorus Uptake of Berseem and Maize
}

\author{
Amjad Ali ${ }^{*}$, Muhammad Sharif', Fazli Wahid' ${ }^{2}$ Zengqiang Zhang1, \\ Syed Noor Muhammad Shah,4, Rafiullah², Sajjad Zaheer5, Farmanullah Khan2, \\ Fazlur Rehman² \\ ${ }^{1}$ College of Resources and Environment, Northwest A\&F University, Yangling, China \\ ${ }^{2}$ Department of Soil \& Environmental Sciences, University of Agriculture, Peshawar, Pakistan \\ ${ }^{3}$ Department of Horticulture, Faculty of Agriculture, Gomal University, D. I. Khan, Pakistan \\ ${ }^{4}$ College of Horticulture, Northwest A\&F University, Yangling, China \\ ${ }^{5}$ Department of Agronomy, University of Agriculture, Peshawar, Pakistan \\ Email: amjadali@aup.edu.pk
}

Received 11 January 2014; revised 18 February 2014; accepted 6 March 2014

Copyright (C) 2014 by authors and Scientific Research Publishing Inc.

This work is licensed under the Creative Commons Attribution International License (CC BY). http://creativecommons.org/licenses/by/4.0/

(c) (i) Open Access

\section{Abstract}

Field experiments were conducted to determine the effect of composts prepared from different organic materials with rock phosphate (RP) on yield and $P$ uptake of berseem and their residual effect on maize crop (cv. Azam) during 2011-2012. Composts prepared from RP fed farm yard manure (FYM), simple FYM, organic waste and city garbage were applied at the rate based on their $P$ concentrations. Composts significantly $(P \leq 0.05)$ increased total dry matter weight of Berseem in first and second cut over control. Residual effect of the prepared composts was determined on yield and plant $P$ uptake of maize in the same layout of Berseem. Maximum and significantly ( $P \leq$ 0.05) higher maize grain yield, total dry matter yield and stover yield of $3161 \mathrm{~kg} \cdot \mathrm{ha}^{-1}, 9633$ $\mathrm{kg} \cdot \mathrm{ha}^{-1}$ and $6472 \mathrm{~kg} \cdot \mathrm{ha}^{-1}$, respectively were recorded by the residual effect of compost of organic waste with half dose of SSP. Thousand grains weight of $220 \mathrm{~g}$ was noted in the treatment of residual effect of compost of RP fed FYM with half dose of SSP. Post harvest soil N and P concentrations improved with composting. Significant $(P \leq 0.05)$ increases in $N$ and $P$ uptake by berseem and maize plants were observed with added composts. Results suggest that the use of composts prepared from different organic materials with RP is environmental friendly and has potential to improve crops yield and plants $\mathrm{N}$ and $\mathrm{P}$ uptakes for a prolonged time.

\footnotetext{
${ }^{*}$ Corresponding author.
}

How to cite this paper: Ali, A., Sharif, M., Wahid, F., Zhang, Z.Q., Shah, S.N.M., Rafiullah, Zaheer, S., Khan, F. and Rehman, F. (2014) Effect of Composted Rock Phosphate with Organic Materials on Yield and Phosphorus Uptake of Berseem and Maize. American Journal of Plant Sciences, 5, 975-984. http://dx.doi.org/10.4236/ajps.2014.57110 


\section{Keywords}

\section{Berseem; Compost; Maize; Residual Effect; Rock Phosphate; Yield}

\section{Introduction}

Nitrogen and Phosphorus are the primary constituents of plants and animals life, playing a vital role in many metabolic processes and phenology of crops and vegetables [1]. Phosphorus has functions of a structural nature in macromolecules such as nucleic acids and of energy transformation as Adenosine Tri-phosphate (ATP) in metabolic pathways of biosynthesis and degradation [2]. Soil type, crops, water, P fertilizer, management practices and climatic conditions of an area are important factors to be considered when attempting to formulate sound P-fertilizer source and application for adequate crops yield response [3]. Composting is a biological process in which microorganisms like bacteria, fungi and other organisms convert organic materials, such as leaves, manure, sludge, paper, grass clippings and food wastes into a soil like material called compost or humus [4]. During composting, microbes utilize carbon of organic material as a source of energy and for synthesis of new microbial cells. Carbon serves as both building block and an energy source for microbes. The use of composts offers several potential benefits including manure handling, enhances soil fertility and reduces environmental risk, enlarges the air spaces in soil, improves its permeability for air and water circulation, improves soil texture, helps retain soil moisture, facilitates the mechanical treatment of heavy clay soil, adds nutrients to the soil, stimulates biological activities, encourages vigorous plant rooting system, helps bind nutrients and prevents them from being leached out of the soil [5] [6]. Organic materials have beneficial effects on fertility and physical properties of soil [7]. The physical properties of soil play an important role in influencing plant growth thereby contributing to efficient crop production [8]. Mulching soil surface with different organic materials improves soil biological activities, retains soil moisture for longer time and helps to control weeds [9]. Farm yard manure (FYM) on an average contains $0.5 \% \mathrm{~N}, 0.2 \% \mathrm{P}_{2} \mathrm{O}_{5}$ and $0.5 \% \mathrm{~K}_{2} \mathrm{O}$ [10]. Application of organic materials to the soil reduces the dependence on chemical fertilizers and helps microorganisms to produce polysaccharides, which improve the soil conditions [11] [12]. Rock Phosphate enriched manures maintain higher levels of P in soil solution for a longer period than the fertilizer alone. Besides a low input technology, it has been claimed that composting manures with RP enhances the dissolution. Berseem (Trifoliumalexandrinum), the most common winter and spring fodder in many parts of Pakistan is low in phosphorus contents (0.14\%) and abundant in calcium (1.44\%). Owing to a wide calcium phosphorus ratio, animals fed predominantly on berseem unless supplemented with some rich source of phosphorus like grains may suffer from phosphorus deficiency syndromes [13]. Maize (Zea mays L.) is a kharif crop, also called corn, and is a very important food grain crop after wheat and rice in the world. The main principle maize growing areas in Pakistan lie in the province of Khyber Pakhtunkhwa and Punjab provinces. Peshawar region both in production and consumption occupies a unique position. The maize crop has the potential to high yielding but its yields production is low in per unit area in Pakistan when compared with advanced other countries as they produced more yields. The area of productions and yields of maize during 2010-11 in Pakistan was 974,200 ha (3,707,000 tons production) and $3805 \mathrm{~kg} \cdot \mathrm{ha}^{-1}$, respectively. The area of production and yield during the similar period in Khyber Pakhtunkhwa was 422,900 ha, (740,500 tons) and $1751 \mathrm{~kg} \cdot \mathrm{ha}^{-1}$, respectively [14]. Keeping in view the importance of $\mathrm{P}$ in crops production and improving its solubility from rock phosphate (RP) through composting, this study was planned to determine and compare the effect of composts prepared from different organic materials with RP on yield and P uptake of berseem and their residual effect on maize crops.

\section{Materials and Methods}

Experiments were conducted in New Developmental Research farms, University of Agriculture, Pehawar, Pakistan to determine and compare the effect of composts prepared from different organic materials with RP on yield and P uptake of berseem and their residual effect on maize crops. Berseem with a seed rate of $20 \mathrm{~kg} \cdot \mathrm{ha}^{-1}$ was broadcasted in Randomized Complete Block Design with three replications. There were 11 treatments, each of $3 \times 5 \mathrm{~m}^{2}$ size. Composts prepared from City Garbage, Organic waste, Simple FYM and RP fed FYM mixed with RP at the ratio of 2.0 part of organic materials and 1.0 part of RP were applied at the rate of 9912, 8380, 
4529 and $4444 \mathrm{~kg} \cdot \mathrm{ha}^{-1}$, respectively on the basis of their P concentration to provide $90 \mathrm{~kg} \cdot \mathrm{P} \cdot \mathrm{ha}^{-1}$. Chemical fertilizers $\mathrm{N}$ and $\mathrm{K}$ were applied at the rate of 30 and $60 \mathrm{~kg} \cdot \mathrm{ha}^{-1}$, respectively in the form of urea and SOP. Nitrogen was applied as split application whereas all $\mathrm{P}$ and $\mathrm{K}$ were applied at sowing time. The maize variety Azam was grown with a seed rate of " $120 \mathrm{~kg} \cdot \mathrm{ha}^{-1}$ " in the field on the same layout of berseem. Fertilizers N and K were applied at the rate of $120-60 \mathrm{~kg} \cdot \mathrm{ha}^{-1}$ respectively in the form of urea and SOP. No P was applied to this crop. Residual effect of $\mathrm{P}$ applied at the rate of $90 \mathrm{~kg} \cdot \mathrm{ha}^{-1}$ to berseem crop in form of SSP and composts were determined on current maize crop. A composite soil sample (0 - $20 \mathrm{~cm}$ depth) was collected from the experimental site before seed sowing and fertilizers application. All the recommended agronomic practices i.e. irrigation, pest control were uniformly kept in all the treatments. The mean temperature during berseem and maize crop was $16.8^{\circ} \mathrm{C}$ and $32.67^{\circ} \mathrm{C}$ respectively, while relatively humidity $58 \%$ and $48.33 \%$ respectively during the crops growth seasons. Soil samples at the depth of $0-20 \mathrm{~cm}$ were also collected from each treatment after crop harvest. Soil samples were air dried ground, sieved through $2 \mathrm{~mm}$ sieve and packed in labeled plastic bags for laboratory analysis. Representative plant samples at maturity stage were collected randomly from each treatment to evaluate effect of different treatments on plants $\mathrm{N}$ and $\mathrm{P}$ uptake. Soil samples were analyzed for Soil Texture [15], Soil pH [16], Soil Organic Matter [17], Lime [18], AB-DTPA extractable P [19], total N [20]. Plant samples from each treatment were analyzed by wet digestion method for the determination of $\mathrm{N}$ and $\mathrm{P}$ concentrations. Total dry matter, grain and stover yields and thousand grain weights were recorded after threshing the bundles of berseem and maize plants from each treatment. The data collected were analyzed statistically according to the procedure as given by Steel \& Torrie [21] using MSTATC package and Least Significant Difference (LSD) test was used for any significant difference among the treatments.

\section{Results and Discussion}

Soil under investigations was silty clay loam, alkaline calcareous in nature, low in organic matter contents (0.88\%), low in available $\mathrm{P}\left(5.75 \mathrm{mg} \cdot \mathrm{kg}^{-1}\right)$ and total $\mathrm{N}(0.08 \%)$ concentrations. The prepared composts were analyzed for $\mathrm{N}$ and $\mathrm{P}$ concentrations. Total $\mathrm{N}$ concentration in the compost of RP fed FYM under investigations was $1.291 \%$, Simple FYM 1.269\%, Organic waste $1.257 \%$ and City garbage $1.36 \%$. There were $2.03 \%$, 1.99\%, $1.07 \%$ and $0.91 \% \mathrm{P}$ concentrations in these composts with $\mathrm{pH}$ values of 8.2, 8.2, 10.2 and 8.8, respectively.

\subsection{Total Dry Matter Yield kg·ha-1 of Berseem}

Statistical analysis of the data indicated that RP composted organic materials significantly $(\mathrm{P} \leq 0.05)$ affect the dry matter (DM) yield of Berseem (Table 1). Data show that the highest dry matter yield of 4000, $3767 \mathrm{Kg} \cdot \mathrm{ha}^{-1}$ with $85 \%$ and 109\% increase respectively, over control was observed in treatments where RP fed FYM + 1/2 SSP were applied followed by treatments receiving city garbage in both cuts. Lowest berseem dry matter yield of $2167,1800 \mathrm{~kg} \cdot \mathrm{ha}^{-1}$ was noted in control in both cuts and was statistically similar to the second and third treat-

Table 1. Berseem total dry matter yield in two cuts as affected with composts of different organic materials.

\begin{tabular}{|c|c|c|c|c|}
\hline \multirow{2}{*}{ Treatments } & \multicolumn{2}{|c|}{ First cut Yield } & \multicolumn{2}{|c|}{ Second cut Yield } \\
\hline & $\mathrm{Kg} \mathrm{ha}^{-1}$ & \% Increased & $\mathrm{Kg} \mathrm{ha}^{-1}$ & \% Increased \\
\hline Control (No fertilizers) & $2167 \mathrm{e}^{*}$ & & $1800 \mathrm{e}^{*}$ & \\
\hline $\mathrm{N}$ and $\mathrm{K}$ fertilizers & $2500 \mathrm{de}^{* *}$ & 15 & $2250 \mathrm{de}^{* *}$ & 25 \\
\hline Compost of RP fed FYM + RP (C-I) & 2767 de & 28 & 2500 de & 39 \\
\hline Compost of Simple FYM + RP (C-II) & 3167 bcd & 46 & 2967 bcd & 65 \\
\hline Compost of Organic Waste + RP(C-III) & $3933 \mathrm{ab}$ & 82 & $3717 \mathrm{ab}$ & 106 \\
\hline Compost of City Garbage + RP (C-IV) & 2667 de & 23 & 2517 de & 40 \\
\hline C-I + half dose of SSP & $4000 \mathrm{a}$ & 85 & $3767 \mathrm{a}$ & 109 \\
\hline C-II + half dose of SSP & 3567 abc & 65 & 3383 abc & 88 \\
\hline C-III + half dose of SSP & 2833 cde & 31 & $2650 \mathrm{~cd}$ & 47 \\
\hline C-IV + half dose of SSP & $3000 \mathrm{~cd}$ & 38 & 2767 cd & 54 \\
\hline Full dose of recommended SSP & $3067 \mathrm{~cd}$ & 42 & $2883 \mathrm{~cd}$ & 60 \\
\hline $\mathrm{LSD}=\mathrm{P} \leq 0.05$ & 776.94 & & 756.72 & \\
\hline
\end{tabular}

\footnotetext{
${ }^{*}$ Means are different significantly in columns at $\mathrm{P} \leq 0.05$.
} 
ment of this experiment. These results are in consistency with. Abdelaziz et al. [22] and Halil et al. [23] who found that dry matter $(\mathrm{DM})$ yield was increased significantly $(\mathrm{P} \leq 0.05)$ by the application of RP composted with organic materials. Rajput et al. [24] concluded that the application of farmyard manure @ $10 \mathrm{t}^{\mathrm{h}} \mathrm{ha}^{-1}$ had significant residual effect in improving yield attributes, yields (grain, stover and biological), nutrient content in grain and stover and nutrient uptake by succeeding maize after wheat. Eghbal et al. [25] found that the residual effects of manure and compost application increased the crop production for one growing season and influenced the soil properties for several years.

\subsection{Post Harvest Soil ECe, pH Values and Soil Organic Matter (SOM) of Berseem Field}

Data regarding effect of RP alone and mixing with different organic fertilizers on post Berseem harvest soil ECe, $\mathrm{pH}$ values and soil organic matter (SOM) content are presented in Table 2. It was obvious from the mean values of the data that higher ECe of $0.71 \mathrm{dSm}^{-1}$ was noted in the treatment where RP fed manure was applied which was similar with other treatments with a narrow range fluctuation. The lower ECe $\left(0.47 \mathrm{dSm}^{-1}\right)$ was found in control. Data indicated that the treatments where RP composted organic materials were applied showed a decreasing trend in soil $\mathrm{pH}$ due to mineralization and release of hydrogen $\left(\mathrm{H}^{+}\right)$ions. Mbakaya et al. [26] reported that the use of RP composted organic materials slightly decrease the $\mathrm{pH}$ values of soil, which was due to the release of $\mathrm{H}^{+}$during the nitrification process of fertilizers. Maximum soil organic matter contents of $0.97 \%$ were observed in treatments where compost of organic waste was applied followed by the treatments of compost of city Garbage + half dose SSP (Table 2). Similar result was shown by Tomayo et al. [27] observed that the combination of RP with organic manure enhanced the organic matter content of soil.

\subsection{Total Phosphurus and Nitrogen Concentration in Berseem}

Plant N and P concentration were observed in two cuts of berseem (Table 3). Statistical analysis of the data shows that plant P concentration was found higher $(0.382 \%, 0.397 \%)$ in the treatments having RP fed FYM + 1/2 SSP followed by treatments receiving Simple FYM + 1/2 SSP in both first and second cut. The lower P concentration $(0.101 \%, 0.144 \%)$ was recorded in control having no fertilizer in both cuts. Waldrip et al. [28] showed that $\mathrm{P}$ values increased as the crop matured. It is obvious from the table that $\mathrm{N}$ concentration was found higher $(2.917 \%, 3.069 \%)$ in the treatments having RP fed FYM + 1/2 SSP followed by treatments receiving city garbage. The lower $\mathrm{N}$ concentration $(1.66 \%, 1.66 \%)$ was recorded in control having no fertilizer in both cuts. These finding were found in line with the work of Abdelaziz et al. [22] and Halil et al. [23]. Higher amount of available nitrogen in soil amended with NPK + FYM have been reported many scientists while improved dehydrogenase activity in organically amended soils was in agreement with the reports of Tejada et al. [29].

Table 2. Post harvest soil organic matter content, ECe and $\mathrm{pH}$ values as affected by the composts of different organic materials of Berseem field.

\begin{tabular}{|c|c|c|c|}
\hline Treatments & SOM (\%) & $\mathrm{pH}(1: 5)$ & $\mathrm{EC}\left(\mathrm{dSm}{ }^{-1}\right)$ \\
\hline Control (No fertilizers) & $0.28 \mathrm{~d}$ & $7.6 \mathrm{a}$ & $0.47 \mathrm{c}$ \\
\hline $\mathrm{N}$ and $\mathrm{K}$ fertilizers & $0.44 \mathrm{~cd}$ & $7.6 \mathrm{ab}$ & $0.48 \mathrm{c}$ \\
\hline Compost of RP fed FYM + RP (C-I) & $0.51 \mathrm{bcd}$ & 7.2 abcd & $0.71 \mathrm{a}$ \\
\hline Compost of simple FYM + RP (C-II) & $0.38 \mathrm{~cd}$ & $7.1 \mathrm{~cd}$ & $0.68 \mathrm{ab}$ \\
\hline Compost of Organic Waste + RP(C-III) & $0.97 \mathrm{a}$ & $7.1 \mathrm{~cd}$ & $0.68 \mathrm{ab}$ \\
\hline Compost of City Garbage+RP (C-IV) & $0.68 \mathrm{abc}$ & $7.2 \mathrm{bcd}$ & 0.69ab \\
\hline C-I + Half dose of SSP & $0.82 \mathrm{ab}$ & $6.9 \mathrm{~d}$ & $0.65 \mathrm{ab}$ \\
\hline C-II + Half dose of SSP & $0.76 \mathrm{ab}$ & $7.0 \mathrm{~d}$ & $0.61 \mathrm{~b}$ \\
\hline C-III + Half dose of SSP & $0.77 \mathrm{ab}$ & 7.3 abcd & 0.69ab \\
\hline C-IV+ Half dose of SSP & $0.96 \mathrm{a}$ & $7.2 \mathrm{~cd}$ & $0.68 \mathrm{ab}$ \\
\hline Full dose of recommended SSP & $0.45 \mathrm{~cd}$ & 7.5 abc & $0.68 \mathrm{ab}$ \\
\hline $\mathrm{LSD} \leq 0.05$ & 0.34 & 0.24 & 0.045 \\
\hline
\end{tabular}

${ }^{*}$ Means are different significantly in columns at $\mathrm{P} \leq 0.05$ 
Table 3. Total phosphorus and Nitrogen concentration (\%) in two cuts of Berseem as affected with composts of different organic materials.

\begin{tabular}{|c|c|c|c|c|}
\hline \multirow{2}{*}{ Treatments } & \multicolumn{2}{|c|}{ Plant Phosphurus \% } & \multicolumn{2}{|c|}{ Plant Nitrogen \% } \\
\hline & First cut & Second cut & First cut & Second cut \\
\hline Control (No fertilizers) & $0.1001 \mathrm{e}^{*}$ & $0.1435 \mathrm{~g}$ & $1.6567 \mathrm{e}$ & $1.6567 \mathrm{e}$ \\
\hline $\mathrm{N}$ and $\mathrm{K}$ fertilizers & $0.1829 \mathrm{~d}$ & $0.2519 \mathrm{e}$ & $2.0067 \mathrm{~d}$ & $2.1933 \mathrm{~d}$ \\
\hline Compost of RP fed FYM + RP (C-I) & $0.2388 \mathrm{~cd}$ & $0.2113 \mathrm{f}$ & $2.0417 \mathrm{~d}$ & $2.1700 \mathrm{~d}$ \\
\hline Compost of simple FYM + RP (C-II) & 0.2599 bc & 0.2680 de & $2.6950 \mathrm{ab}$ & $2.8233 \mathrm{ab}$ \\
\hline Compost of Organic Waste + RP(C-III) & 0.2583 bcd & $0.2655 \mathrm{e}$ & $2.1700 \mathrm{~d}$ & $2.4033 \mathrm{~d}$ \\
\hline Compost of City Garbage + RP(C-IV) & 0.2864 bc & 0.3116 bc & 2.8117 a & 2.9633 a \\
\hline C-I + Half dose of SSP & 0.3816 a & 0.3966 a & $2.9167 \mathrm{a}$ & 3.0683 a \\
\hline C-II + Half dose of SSP & $0.3326 \mathrm{ab}$ & $0.3410 \mathrm{~b}$ & $2.7300 \mathrm{ab}$ & $2.9050 \mathrm{ab}$ \\
\hline C-III + Half dose of SSP & $0.2498 \mathrm{~cd}$ & $0.2611 \mathrm{e}$ & $2.4850 \mathrm{bc}$ & 2.6833 bc \\
\hline C-IV+ Half dose of SSP & $0.2862 \mathrm{bc}$ & $0.2980 \mathrm{~cd}$ & $2.6483 \mathrm{ab}$ & $2.8583 \mathrm{ab}$ \\
\hline Full dose of recommended SSP & $0.3144 \mathrm{abc}$ & 0.3141 bc & $2.2633 \mathrm{~cd}$ & $2.4267 \mathrm{~cd}$ \\
\hline $\operatorname{LSD}(\mathrm{P} \leq 0.05)$ & 0.7703 & 0.0300 & 0.2848 & 0.2702 \\
\hline
\end{tabular}

*Means are different significantly in columns at $\mathrm{P} \leq 0.05$.

\subsection{Plant Nitrogen and Phosphorus Uptake of Berseem}

Data on Nitrogen and Phosphorus uptake by berseem as affected by RP composted organic material alone and in combination with inorganic fertilizers are given in Table 4. N uptake 116.7, $115.6 \mathrm{Kg} \cdot \mathrm{ha}^{-1}$ with $225 \%$, 288\% increase, respectively over control was found in treatments where combinations of RP fed FYM + 1/2 SSP were applied followed by city garbage in both cuts respectively, which were statistically at par with each others. The minimum plant $\mathrm{N}$ uptake of 35.91 and $29.83 \mathrm{Kg} \cdot \mathrm{ha}^{-1}$ was noted in control. Awaad et al. [30] reported that $\mathrm{N}$ uptake in plant increased by the combined application of phosphatic source such as RP composted fertilizers (Table 4). Data regarding plant $\mathrm{P}$ uptake by berseem revealed $603 \%$ and $479 \%$ significant $(\mathrm{P} \leq 0.05)$ increase over control plot with 15.27 and $14.9 \mathrm{Kg} \cdot \mathrm{ha}^{-1} \mathrm{P}$ uptake, where RP fed FYM + 1/2 SSP were used. This increased P uptake was followed by the treatments where simple FYM + 1/2 SSP was applied. Minimum plant P uptake of 2.18 and $2.59 \mathrm{Kg} \cdot \mathrm{ha}^{-1}$ was recorded in control where no fertilizer was applied. These results are similar to Erdal et al., [31] who reported that nutrients accumulations in plant were enhanced by the use of RP composted and inorganic materials. However, in areas where the risk of $\mathrm{P}$ transport in runoff is not a concern, the increased plant available $\mathrm{P}$ level in soil and N-based manure or composts application can contribute to crop P uptake for up to 10 years without any additional $\mathrm{P}$ addition [25] [32].

\subsection{Yield and Yield Component of Maize}

The yield of maize grain as affected by the residual composts effects with RP is given in Table 5. Significantly $(\mathrm{P}<0.05)$ increased maize grain yield of $3161 \mathrm{Kg} \cdot \mathrm{ha}^{-1}$ was obtain by the residual composts effects of "organic waste (C-III)" applied with "semi dose of single super phosphate", followed by the compost of "RP fed dung (C-I)" and "1/2 dose of single super phosphate" and lowest grain yield (2223 kg·ha $\left.{ }^{-1}\right)$ was noted in control where fertilizer was not applied. Eghbal et al. [25] found that the residual effect of manure and composts function improve the production of crops for the period of one growing season and the properties of soil effect for a number of years. Data regarding total dry matter yield of maize has significantly affect through the residual effects of different compost. Highest dry matters (DM) yields of $9633 \mathrm{Kg} \cdot \mathrm{ha}^{-1}$ was found by the composts residual effects of organic waste and semi dose of single super phosphate followed by the compost of "city garbages" applied with $1 / 2$ dose of single super phosphate. Treatment where fertilizer was not applied indicates the lowest $6451 \mathrm{Kg} \cdot \mathrm{ha}^{-1}$ total dry "matters yields" of maize. Rajput et al. [24] realized that farmyard manure application @

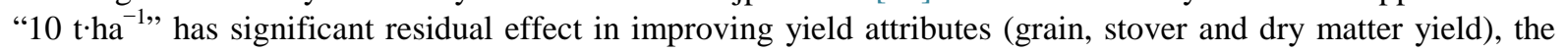
nutrient contents in grain of crop, stover yield and nutrient uptake by succeeding maize after wheat. Data on stover yield of maize crop also shows that the highest stover yield of $6574 \mathrm{~kg} \cdot \mathrm{ha}^{-1}$ was recorded in the treatments of compost of "city garbage and 1/2 dose Single Super Phosphate. The lowest stover yield of $4228 \mathrm{~kg} \cdot \mathrm{ha}^{-1}$ 
Table 4. Effects of the prepared composts on plants N and P uptake of Berseemcrop.

\begin{tabular}{|c|c|c|c|c|}
\hline \multirow{2}{*}{ Treatments } & \multicolumn{2}{|c|}{ Plant $\mathrm{N}$ uptake } & \multicolumn{2}{|c|}{ Plant P uptake } \\
\hline & First cut & Second cut & First cut & Second cut \\
\hline Control (No fertilizers) & 35.90 e & $29.82 \mathrm{e}$ & $2.17 \mathrm{e}$ & $2.58 \mathrm{~g}$ \\
\hline $\mathrm{N}$ and $\mathrm{K}$ fertilizers & $50.17 \mathrm{~d}(40)$ & $49.35 \mathrm{~d}(65)$ & $4.57 \mathrm{~d}(111)$ & 5.67 e (120) \\
\hline Compost of RP fed FYM + RP (C-I) & $56.49 \mathrm{~d}(57)$ & $54.25 \mathrm{~d}(82)$ & $6.61 \mathrm{~cd}(205)$ & 5.28 e (105) \\
\hline Compost of Simple FYM + RP (C-II) & $85.34 \mathrm{ab}(138)$ & $83.76 \mathrm{ab}(181)$ & 8.23 bc (279) & 7.95 de (208) \\
\hline Compost of Organic Waste + RP (C-III) & 85.35 d (138) & 89.32 d (200) & 10.16 bcd(368) & 9.87 e (283) \\
\hline Compost of City Garbage + RP (C-IV) & 74.98 a (109) & 74.58 a (150) & 7.64bc (252) & 7.84 bc (204) \\
\hline C-I + half dose of SSP & 116.67 a (225) & 115.57 a (288) & 15.27 a (603) & 14.94 a (479) \\
\hline C-II + half dose of SSP & $97.37 \mathrm{ab}(171)$ & $98.28 \mathrm{ab}(230)$ & $11.86 \mathrm{ab}(447)$ & $11.54 \mathrm{~b}(347)$ \\
\hline C-III + half dose of SSP & 70.41 bc (96) & 71.11 bc (138) & 7.08 cd (226) & 6.92 e (168) \\
\hline C-IV + half dose of SSP & $79.45 \mathrm{ab}(121)$ & $79.08 \mathrm{ab}(165)$ & 8.59 bc (296) & $8.24 \mathrm{~cd}(219)$ \\
\hline Full dose of recommended SSP & 69.41 cd (93) & 69.97 cd (136) & 9.64 abc (344) & 9.06 bc (251) \\
\hline $\operatorname{LSD}(\mathrm{P} \leq 0.05)$ & 45.45 & 50.66 & 4.78 & 3.65 \\
\hline
\end{tabular}

"Means are different significantly in columns at $\mathrm{P} \leq 0.05 ;{ }^{* *}$ Values in parenthesis show the percent increase over control.

Table 5. Residual effect of composts on grains, total dry matter and stover yields and thousands grain weight of maize.

\begin{tabular}{|c|c|c|c|c|}
\hline \multirow{2}{*}{ Treatments } & Grains Yields & Total dry Matters yield & Stover Yields & \multirow{2}{*}{1000 grain Weight (g } \\
\hline & & $\mathrm{Kg} \cdot \mathrm{ha}^{-1}$ & & \\
\hline Control & $2223 d^{*}$ & $6451 \mathrm{~g}^{*}$ & $4228 \mathrm{e}^{*}$ & $140 \mathrm{f}^{*}$ \\
\hline $\mathrm{N}$ and K Fertilizer & $2592 \mathrm{~b}$ & $7083 \mathrm{f}$ & 4492 e & 159 ef \\
\hline Compost of RP fed dung (C-I) & $2931 \mathrm{~b}$ & $7397 \mathrm{f}$ & 4466 e & $203 a b$ \\
\hline Compost of simple dung (C-II) & $2923 \mathrm{abc}$ & 8233 e & $5310 \mathrm{~d}$ & 168 de \\
\hline Compost of organic wastes (C-III) & $2555 \mathrm{~cd}$ & 8700 cde & $6145 \mathrm{ab}$ & $216 \mathrm{ab}$ \\
\hline Compost of city garbage (C-IV) & $2842 \mathrm{abc}$ & 8200 e & $5358 \mathrm{~cd}$ & $189 \mathrm{~b}$ \\
\hline C-I+ Half dose of recommended SSP & $2983 a b$ & 8993 bcd & $6010 \mathrm{~b}$ & $220 \mathrm{a}$ \\
\hline C-II + Half dose of recommended SSP & 2891abc & 8433 de & $5543 \mathrm{bcd}$ & 219 a \\
\hline C-III + Half dose of recommended SSP & 3161 a & 9633 a & $6472 \mathrm{a}$ & $201 \mathrm{ab}$ \\
\hline C-IV + Half dose of recommended SSP & $2893 \mathrm{abc}$ & $9467 a b$ & $6574 a$ & $212 a b$ \\
\hline Full dose of recommended SSP & 2695 bc & $9237 \mathrm{~b}$ & $6542 \mathrm{a}$ & 186 cde \\
\hline $\operatorname{LSD}(\mathrm{P} \leq 0.05)$ & 393.45 & 627.65 & 662.71 & 26.925 \\
\hline
\end{tabular}

"Means are different significantly in columns at $\mathrm{P} \leq 0.05$.

was obtained in control treatments. Rajput et al. [24] concluded that the farmyard manure used @ of "10 t·ha"-1," have significant residual effect in improving stover yield. Residual effect of composts of different materials on thousand grains weight of maize crop is expressed in Table 5. Data indicated that highest thousand (1000) grains weight of 220 g was well-known by the treatment of residual compost effects "RP fed dungs (C-I)" and half dose SSP. In case of control treatment lowest as $140 \mathrm{~g}$ thousand grains weight of maize crop was obtained without application of fertilizer. Song et al. [33] reported that combined use of organic and NPK fertilizer effect significantly on thousand grains weight of maize.

\subsection{Post-Harvest Soil N and P Concentrations of Maize}

The concentration of soil $\mathrm{N}$ and $\mathrm{P}$ after harvested as influenced via the residual effects of composts are show in Table 6. Data on soil total $\mathrm{N}$ content revealed that maximum $\left(1458.3 \mathrm{mg} \cdot \mathrm{N} \cdot \mathrm{kg}^{-1}\right)$ was receivedwithin the treatments of residual composts effects of organic waste (C-III) follow by the residual effects of "compost” of RP fed dung and semi dose single super phosphate. The lowest nitrogen content in soil after maize crop harvest as $438.3 \mathrm{mg} \cdot \mathrm{kg}^{-1}$, was recorded by treatments of control which was not fertilized (Table 6). Esilaba et al. [34] investigated that the organic manure and NPK fertilizer application increased yield of maize and improve the 
Table 6. Residual effects of composts on post harvested soil $\mathrm{N}$ and $\mathrm{P}$ concentrations.

\begin{tabular}{ccc}
\hline Treatment & Total N & ABD-TPA extractable P \\
\hline Control & & $\left(\mathrm{mg} \cdot \mathrm{Kg}^{-1}\right)$ \\
N and K' Fertilizer & $438.3 \mathrm{e}$ & $0.27 \mathrm{c}^{*}$ \\
Composts of RP fed dungs (C-I) & $729.2 \mathrm{de}$ & $0.400 \mathrm{c}$ \\
Composts of simple dungs (C-II) & $1400.0 \mathrm{ab}$ & $0.83 \mathrm{bc}$ \\
Compost of organic wastes (C-III) & $737.5 \mathrm{de}$ & $1.06 \mathrm{bc}$ \\
Compost of city garbages (C-IV) & $1458.3 \mathrm{a}$ & $0.85 \mathrm{bc}$ \\
C-I + Half dose' of recommended 'SSP' & $908.3 \mathrm{~cd}$ & $1.06 \mathrm{bc}$ \\
C-II + Half dose' of recommended 'SSP' & $1400.0 \mathrm{ab}$ & $2.44 \mathrm{a}$ \\
C-III + Half dose' of recommended 'SSP' & $1347.5 \mathrm{ab}$ & $1.84 \mathrm{ab}$ \\
C-IV + Half dose of recommended SSP & $1020.8 \mathrm{bcd}$ & $1.23 \mathrm{bc}$ \\
Full dose of recommended SSP & $1201.7 \mathrm{~b}$ & $1.29 \mathrm{bc}$ \\
LSD(P $\leq 0.05)$ & $1187.8 \mathrm{abc}$ & $1.57 \mathrm{~b}$ \\
\hline
\end{tabular}

${ }^{*}$ Means are different significantly in columns at $\mathrm{P} \leq 0.05$.

concentration of soil nitrogen. Data regarding extractable soil $\mathrm{P}$ after crop harvest as affected by the residual effect of composts are shown in Table 6. The highest AB-DTPA extractible P content in soil was recorded as 2.44 $\mathrm{mg} \cdot \mathrm{kg}^{-1}$ by treatment of the residual effect of “compost fed dung” and 1/2 dose single super phosphate. Minimum P content observed was $0.27 \mathrm{mg} \cdot \mathrm{kg}^{-1}$ in the treatment of control without fertilized. Laskar et al. [35] reported the rock phosphate alone and in combined with organic manure significantly enhance the content of organic P in soil. Mehdi et al. [36] reported that the growth and nutrition of sorghum fodder significantly effect by residual effect of P. Eghball et al. [25] found that the source of $\mathrm{N}$ and $\mathrm{P}$ from residual compost and manure application effects on the grain yield of corn. The $\mathrm{N}$ may effects for the period of one growing season due to high mobility and leaching risk in soil and soil P uptake contribute for four year due to low mobility.

\subsection{Plant N and P Concentrations of Maize}

The concentrations of $\mathrm{N}$ and $\mathrm{P}$ in plant as affected by the residual effects of compost are shown in given Table 7 . After the harvesting of maize crop, the concentration of $\mathrm{N}$ in maize plants improved significantly $(\mathrm{P} \leq 0.05)$ more than the control. Highest total $\mathrm{N}$ concentration $(0.799 \%)$ were observed by the treatment of the residual composts effects of fed dung + semi dose Single Super Phosphate, followed by compost of city garbage (0.779\%) and organic wastes + half dose of SSP (0.778\%). In control treatment, minimum N content was found as $0.345 \%$. The analysis of $\mathrm{P}$ data showed that the plant maximum $\mathrm{P}$ concentration as $0.237 \%$ was observed by treatments of compost of the residual effects of organic waste with 1/2 dose of single super phosphate, followed with the compost of city garbages (C-IV).

\subsection{N and P Uptake of Maize}

The data regarding uptake of $\mathrm{N}$ showed that the highest $\mathrm{N}$ uptake as $75 \mathrm{~kg} \cdot \mathrm{ha}^{-1}$ was record into treatments which received effects of residual composts of organic waste with $1 / 2$ dose of recommended single super phosphate (Table 8). The lowest uptake of $\mathrm{N}$ as $22 \mathrm{~kg} \cdot \mathrm{ha}^{-1}$ was found inside control treatment of without fertilized. The data regarding $\mathrm{P}$ uptake showed that highest uptake of $\mathrm{P}$ as $23 \mathrm{~kg} \cdot \mathrm{h}^{-1}$ was observed within the treatment effects of residual compost of organic waste and half $1 / 2$ dose of single super phosphate followed the compost of city garbages (C-IV), while lowest uptake of $\mathrm{P}$ as $8 \mathrm{Kg} \cdot \mathrm{ha}^{-1}$ was seen in the treatments of control without fertilized (Table 8). Erdal et al. (2000) examined the accumulation increased in plant N and P when dung as organic material and chemical fertilizer was applied. Eghbal (2004) also reported that the effects of residual composts of manure application was increased significantly plant $\mathrm{P}$ and $\mathrm{N}$ available concentrations.

\section{Conclusion}

Composts prepared from city garbage, organic waste, farm yard manures with RP are cheap and indigenous 
Table 7. Residual effects of compost on Maize N and P concentrations.

\begin{tabular}{ccc}
\hline Treatment & Plant N & Plant P \\
\cline { 2 - 3 } Control & & (\%) \\
N and K Fertilizer & $0.345 \mathrm{c}^{*}$ & $0.122 \mathrm{e}^{*}$ \\
Compost of RP fed dung (C-I) & $0.499 \mathrm{bc}$ & $0.126 \mathrm{de}$ \\
Compost of simple dung (C-II) & $0.759 \mathrm{a}$ & $0.173 \mathrm{~b}$ \\
Compost of organic wastes (C-III) & $0.501 \mathrm{bc}$ & $0.135 \mathrm{cde}$ \\
Compost of city garbage (C-IV) & $0.791 \mathrm{a}$ & $0.193 \mathrm{ab}$ \\
C-I + Half dose of recommended SSP & $0.779 \mathrm{a}$ & $0.232 \mathrm{a}$ \\
C-II + Half dose of recommended SSP & $0.799 \mathrm{a}$ & $0.191 \mathrm{ab}$ \\
C-III + Half dose of recommended SSP & $0.659 \mathrm{ab}$ & $0.168 \mathrm{bcde}$ \\
C-IV + Half dose of recommended SSP & $0.778 \mathrm{a}$ & $0.237 \mathrm{a}$ \\
Full dose of recommended 'SSP' & $0.622 \mathrm{~b}$ & $0.183 \mathrm{bc}$ \\
LSD(P $\leq 0.05)$ & $0.703 \mathrm{ab}$ & $0.204 \mathrm{ab}$ \\
\hline
\end{tabular}

*Means are different significantly in columns at $\mathrm{P} \leq 0.05$.

Table 8. Residual effects of compost on $\mathrm{N}$ and $\mathrm{P}$ uptakes of Maize.

\begin{tabular}{|c|c|c|}
\hline \multirow{2}{*}{ Treatments } & Plant “N” uptake & Plant “P” uptake \\
\hline & \multicolumn{2}{|c|}{$\left(\mathrm{kg} \cdot \mathrm{ha}^{-1}\right)$} \\
\hline Control & $22 c^{*}$ & $8 \mathrm{de}^{*}$ \\
\hline $\mathrm{N}$ and K Fertilizer & $35 \mathrm{bc}$ & 10 c-e \\
\hline “Compost of RP fed dungs (C-I)” & 56 a & $13 \mathrm{~b}-\mathrm{d}$ \\
\hline "Compost of simple dungs (C-II)" & $41 \mathrm{~b}$ & $10 \mathrm{e}$ \\
\hline Compost of organic wastes (C-III) & 69 a & $17 \mathrm{ab}$ \\
\hline Compost of city garbage (C-IV) & $64 \mathrm{a}$ & 19 a \\
\hline C-I+ Half dose of recommended SSP & $72 \mathrm{a}$ & $17 \mathrm{ab}$ \\
\hline "C-II + Half dose” of recommended "SSP” & $56 \mathrm{ab}$ & 14 b-e \\
\hline "C-III + Half dose" of recommended "SSP" & $75 \mathrm{a}$ & 23 a \\
\hline "C-IV + Half dose" of recommended "SSP" & $59 \mathrm{ab}$ & $17 \mathrm{~b}$ \\
\hline "Full dose" of recommended "SSP" & $65 \mathrm{ab}$ & $19 \mathrm{ab}$ \\
\hline $\operatorname{LSD}(\mathrm{P} \leq 0.05)$ & 25 & 6 \\
\hline
\end{tabular}

*Means are significantly different in columns at $\mathrm{P} \leq 0.05$.

source of $\mathrm{P}$ and have potential to improve crop production and plants $\mathrm{N}$ and $\mathrm{P}$ uptake when applied with half dose of SSP. Maximum grains, total dry matter, and stover yield and thousand grains weight were produced by the treatment where the compost of organic waste was applied with half dose of SSP. Post harvest soil N and P concentrations were increased by the addition of composts of different organic materials. Maximum and significantly ( $\mathrm{p} \leq 0.05$ ) increased maize grain yield, total dry matter and stover yield of $3161 \mathrm{~kg} \cdot \mathrm{ha}^{-1}, 9633 \mathrm{~kg} \cdot \mathrm{ha}^{-1}$ and $6472 \mathrm{~kg} \cdot \mathrm{ha}^{-1}$, respectively were observed by the residual effect of composts of organic waste applied with half dose of SSP. Further research is needed to prepare composts of other organic materials with RP on large scale to enhance their P solubility and to determine their direct and residual effects on the growth of different crops at different agroecological zones of Pakistan, in order to reduce the use of P fertilizers and minimize the expenses of crop production.

\section{Acknowledgements}

The authors would like to acknowledge Agricultural Linkage Programme (ALP) of Pakistan Agriculture Research Council for this study. 


\section{References}

[1] Khan, M.A., Sajid, M., Hussain, Z., Rab, A., Marwat, Fazal-I-Wahid, K.B. and Bibi, S. (2013) How Nitrogen and Phosphorus Influence the Phenology of Okra. Pakistan Journal of Botany, 45, 479-482.

[2] Barber, S.A. (1995) Soil Nutrient Bioavailability: A Mechanistic Approach. John \& Wiley Sons, Inc., New York.

[3] Amanullah, M.A., Nawab, K., Shah, Z., Hassan, M., Khan, A.Z., Khalil, S.K., Hussain, Z., Tariq, M. and Rahman, H. (2010) Impacts of Planting Density and P-Fertilizer Source on the Growth Analysis of Maize. Pakistan Journal of Botany, 42, 2349-2357.

[4] Vasilica, S., Virsta, A., Mirela Dusa, E. and Glavan, A.M. (2009) Waste Recycling and Compost Benefits. Notulae Botanicae Horti Agrobotanici Cluj-Napoca, 37, 9-13.

[5] Bertoldi, M.D.D., Vallini, G. and Pera, A. (1983) The Biology of Composting: A Review. Waste Management \& Research, 1, 157-176. http://dx.doi.org/10.1016/0734-242X(83)90055-1

[6] Sarwar, G., Schmeisky, H., Hussain, N., Muhammad, S., Ibrahim, M. and Safdar, E. (2008) Improvement of Soil Physical and Chemical Properties with Compost Application in Rice-Wheat Cropping System. Pakistan Journal of Botany, 40, 275-282.

[7] Hoitink, H.A.J. and Grebus, M.E. (1994) Status of Biological Control of Plant Diseases with Composts. Compost Science \& Utilization, 2, 6-12. http://dx.doi.org/10.1080/1065657X.1994.10771134

[8] Zheljazkov, V.D. and Warman, P.R. (2004) Source-Separated Municipal Solid Waste Compost Application to Swiss Chard and Basil. Journal of Environmental Quality, 33, 542-552. http://dx.doi.org/10.2134/jeq2004.5420

[9] Hashim, S., Marwat, K.B., Saeed, M., Haroon, M., Waqas, M. and Shah, F. (2013) Developing a Sustainable and Eco-Friendly Weed Management System Using Organic and Inorganic Mulching Techniques. Pakistan Journal of Botany, 45, 483-486.

[10] Brannon, C.A. and Sommers, L.E. (1985) Preparation and Characterization of Model Humic Polymers Containing Organic Phosphorus. Soil Biology and Biochemistry, 17, 213-219. http://dx.doi.org/10.1016/0038-0717(85)90117-8

[11] Gaur, A.C. (1992) Bulky Organic Manures and Crop Residues. In: H. Tandon, Ed., Fertilisers, Organic Manures, Recyclable Wastes and Biofertilisers: Components of Integrated Plant Nutrition, Fertiliser Development and Consultation Organisation, New Dehli, 36-43.

[12] Sharif, M., Khattak, R.A. and Sarir, M.S. (2003) Residual Effect of Humic Acid and Chemical Fertilizers on Maize Yield and Nutrient Accumulation. Sarhad Journal of Agriculture, 19, ,

[13] Ranjhan, S.K. (2001) Animal Nutrition in the Tropics. Vikas Publishing House Pvt. Ltd., New Delhi.

[14] MINFAL (2010) Agricultural statistics of Pakistan. Ministry of Food, Agriculture. Livestock (Economic Wing), Islamabad.

[15] Bouyoucos, G.J. (1962) Hydrometer Method Improved for Making Particle Size Analyses of Soils. Agronomy Journal, 54, 464-465. http://dx.doi.org/10.2134/agronj1962.00021962005400050028x

[16] Mclean, E.O. (1982) Soil pH and Lime Requirement. In: A. L. Page, Ed., Methods of Soil Analysis. Part 2. Chemical and Microbiological Properties, American Society of Agronomy, Soil Science Society of America, Madison, 199-224.

[17] Sommers, D.W. and Nelson, L.E. (1996) Total Carbon, Organic Carbon, and Organic Matter. In: Sparks, D.L., Page, A.L., Helmke, P.A., Loeppert, R.H., Soltanpour, P.N., Tabatabai, M.A., Johnston, C.T. and Sumner, M.E., Eds., Methods of Soil Analysis. Part 3-Chemical Methods, Soil Science Society of America Inc., Madison, 961-1010.

[18] Richards, L.A. (1954) Diagnosis and Improvement of Saline and Alkali Soils. Soil Science, 78, 154. http://dx.doi.org/10.1097/00010694-195408000-00012

[19] Soltanpour, P.N. and Schwab, A.P. (1977) A New Soil Test for Simultaneous Extraction of Macro- and Micro-Nutrients in Alkaline Soils 1. Communications in Soil Science \& Plant Analysis, 8, 195-207. http://dx.doi.org/10.1080/00103627709366714

[20] Bremner, J.M. and Mulvaney, C.S. (1982) Nitrogen-Total. In: Page, A.L., Ed., Methods of Soil Analysis. Part 2. Chemical and Microbiological Properties, American Society of Agronomy, Soil Science Society of America, Madison, 595-624.

[21] Steel, R.G.D. and Torrie, J.H. (1980) Principles and Procedures of Statistics, a Biometrical Approach. McGraw-Hill Kogakusha, Ltd., Tokyo.

[22] Abdelaziz, M.E., Pokluda, R. and Abdelwahab, M.M. (2007) Influence of Compost, Microorganisms and NPK Fertilizer upon Growth, Chemical Composition and Essential Oil Production of Rosmarinus officinalis L. Notulae Botanicae Horti Agrobotanici Cluj-Napoca, 35, 86-90.

[23] Yolcu, H., Gunes, A., Dasci, M., Turan, M. and Serin, Y. (2010) The Effects of Solid, Liquid and Combined Cattle Manure Applications on the Yield, Quality and Mineral Contents of Common Vetch and Barley Intercropping Mixture. 
Ekoloji, 19, 71-81. http://dx.doi.org/10.5053/ekoloji.2010.7510

[24] Rajput, S.S., Shaktawat, M.S. and Intodia, S.K. (2007) Residual Effect of Udaipur Rock Phosphate Sources and Farmyard Manure on Productivity and Nutrient Uptake by Succeeding Maize (Zea mays) after Wheat (Triticum aestivum). Indian Journal of Agricultural Science, 77, 145-149.

[25] Eghball, B., Ginting, D. and Gilley, J.E. (2004) Residual Effects of Manure and Compost Applications on Corn Production and Soil Properties. Agronomy Journal, 96, 442-447. http://dx.doi.org/10.2134/agronj2004.0442

[26] Mbakaya, D.S., Odenya, J.O., Njeru, C. and Luteya, J. (2006) Effects of Liming, Organic and Inorganic Fertilizers on Yield of Maize in Western Kenya. Proceeding of the 8th KARI Scientific Conference, Nairobi, 12-17 November 2006, 123-129.

[27] Tomayo, V.A., Munoz, A.R. and Diaz, A.C. (1997) Organic Fertilizer Application to Maiz (Zea mays L.) on Alluvial Soilin a Moderate Climate. Actualidades-Corpoica, 108, 19-24.

[28] Waldrip-Dail, H., He, Z., Erich, S.M. and Honeycutt, W.C. (2009) Soil Phosphorus Dynamics in Response to Poultry Manure Amendment. Soil Science, 174, 195-201. http://dx.doi.org/10.1097/SS.0b013e31819cd25d

[29] Tejada, M.L.G., Suzuki, K., Kuroda, J., Coccioni, R., Mahoney, J.J., Ohkouchi, N., Sakamoto, T. and Tatsumi, Y. (2009) Ontong Java Plateau Eruption as a Trigger for the Early Aptian Oceanic Anoxic Event. Geology, 37, 855-858. http://dx.doi.org/10.1130/G25763A.1

[30] Awaad, M.S., Rashad, A.A. and Bayoumi, M.A. (2009) Effect of Farmyard Manure Combined with Some Phosphate Sources on the Productivity of Canola Plants Grown on a Sandy Soil. Research Journal of Agriculture and Biological Sciences, 5, 1176-1181.

[31] Erdal, I., Bozkurt, M.A., Çimrin, K.M., Karaca, S. and Saglam, M. (2000) Effects of Humic Acid and Phosphorus fertilizer Application on Growth and Phosphorus Uptake of Maize (Zea mays L.) Grown on a Calcareous Soil. Turkish Journal of Agriculture \& Forestry, 24, 663-668.

[32] Ginting, D., Kessavalou, A., Eghball, B. and Doran, J.W. (2003) Greenhouse Gas Emissions and Soil Indicators Four Years after Manure and Compost Applications. Journal of Environmental Quality, 32, 23-32. http://dx.doi.org/10.2134/jeq2003.2300

[33] Song, Y.I., Ming, Y.F., Zaohua, Y. and Yuan, F.M. (1998) A Fixed Location Study on the Effect of Different Combination of Fertilizers on Biological Characters and Yield of Winter Wheat. Soils and Fertility Beijing, 1, 15-18.

[34] Esilaba, A.O., Reda, F., Ransom, J.K., Bayu, W., Woldewahid, G. and Zemichael, B. (2000) Integrated Nutrient Management Strategies for Soil Fertility Improvement and Striga Control in Northern Ethiopia. African Crop Science Journal, 8, 403-410. http://dx.doi.org/10.4314/acsj.v8i4.27680

[35] Laskar, B.K., De, G.K., Debnath, N.C. and Basak, R.K. (1990) Phosphorus Availability and Transformation from Mussoorie rockphosphate in Acid Soils. Environment and Ecology, 8, 612-616.

[36] Mehdi, S., Mehdi, M., Rehman, O., Sarfraz, M., Ahmad, B. and Afzal, S. (2010) Residual Effect of Wheat Applied Phosphorus on Sorghum Fodder in a Sandy Loam Soil (Report). Pakistan Journal of Science, 62, 322-324.

\section{Abbreviations}

AB-DTPA: Ammonium Bicarbonate DiethyleneTriaminePentaacetic Acid

ATP: Adenosine Tri-phosphate

DM: Dry Matter

ECe: Electrical Conductivity in Extract

FYM: Farm Yard Manure

LSD: Least Significant Difference

$\mathrm{N}$ : Nitrogen

P: Phosphorus

K: Potassium

RP: Rock Phosphate

SOM: Soil Organic Matter

SOP: Sulphate of Potash

SSP: Single Super Phosphate 